\title{
PROFESIONALISME APARATUR SIPIL NEGARA (ASN) DI KANTOR CAMAT BUKIT RAYA KOTA PEKANBARU
}

\author{
Prihati, Harsini dan Sri Roserdevi Nasution \\ Universitas Lancang Kuning \\ Email : prihati@unilak.ac.id
}

\begin{abstract}
Bangsa Indonesia selalu dihadapkan kepada masalah bagaimana membangun pemerintahan yang bersih dan baik (good governance and clean government). Birokrasi yang diharapkan mampu menjadi motivator dan sekaligus menjadi katalisator dari bergulirnya pembangunan, tidak mampu menjalankan perannya sebagai birokrasi modern tidak hanya mengedepankan kemampuan menyelenggarakan tugas dan fungsi organisasi saja tetapi juga mampu merespons aspirasi publik kedalam kegiatan dan program organisasi dan mampu melahirkan inovasi baru yang bertujuan untuk mempermudah kinerja organisasi dan sebagai bagian dari wujud aparat yang profesional. Dalam perspektif administrasi publik Indonesia dikenal berbagai macam patologi yang membuat birokrat atau aparat tidak profesional dalam menjalankan tugas dan fungsinya antara lain adalah rendahnya motivasi untuk melakukan perubahan dan berinovasi.

Mengingat urgensitas peran aparatur dalam menyelenggarakan peran dan fungsinya, perlu kiranya dicari dan dirumuskan suatu pendekatan strategis untuk membangun wajah baru aparatur profesional yang handal, tanggap, inovatif fleksibel dan tidak prosedural dalam memberikan pelayanan dan penyelenggaraan pembangunan.Tipe penelitian ini adalah deskriptif dengan pendekatan kualitatif, teknik pengumpulan data dengan menggunakan wawancara mendalam dan dokumentasi. Adapun pemilihan informan dengan menggunakan teknik purposive sampling sehingga didapatlah informan yang sesuai dengan kriteria penelitian. Selanjutnya analisis data melalui interpretasi etik dan emik kemudian dielaborasi dalam kajian tata laksana kepemerintahan sesuai dengan pembahasan yang diteliti.Hasil penelitian responsifitas dan inovasi aparatur Kecamatan Bukitraya baik dalam rangka pelayanan kepada masyarakat maupun dalam pelaksanaan tugas-tugas yang lain sudah mulai mengarah kepada visi dari kecamatan Bukitraya yaitu Terwujudnya Kecamatan Bukitraya Yang Profesional Dalam Penyelenggaraan Pemerintahan Dan Pelayanan Kepada Masyarakat, hanya saja belum terlaksana secara optimal.
\end{abstract}

Kata Kunci: Profesionalisme, Inovasi, Responsifitas.

Abstract
The Indonesian people are always faced with the problem of how to build a clean government and good (good governance and clean government). Bureaucracy is expected to be a motivator and as well as a catalyst of the passing of development, not able to perform its role as a modern bureaucracy not only promote the capacity to organize the tasks and functions of the organization, but also capable of responding to the aspirations of the public into the activities and programs of the organization and is able to bring new innovations aimed at facilitate the performance of the organization and as a part of the manifestation of the professional apparatus. In the perspective of public administration Indonesia known to a wide range of pathologies that make bureaucrats or officials are not professional in their duties and functions include low motivation to change and innovate.

Given the urgency of the apparatus role in organizing role and function, it would need to be sought and formulated a strategic approach to build the new face of professional personnel that are reliable, responsive, flexible and innovative in providing services and procedural development implementation.This type of research is descriptive qualitative approach, data collection techniques using in-depth interviews and documentation. The selection of informants by using purposive sampling so didapatlah informants in accordance with the criteria. Further analysis of the data through the interpretation of ethics and EMIC is further elaborated in the study of governance in accordance with the governance discussion is being investigated.The results of the study of responsiveness and innovation apparatus Subdistrict Bukitraya well in order to give service to the community as well as in the implementation of the tasks that others have started to lead to the vision of districts Bukitraya namely 
the realization of the District Bukitraya The Professionals In The Governance and Service to Society, it's just not done optimally.

Keywords : Professionalism, Innovation, Responsiveness

\section{PENDAHULUAN}

Profesionalisme pegawai kecamatan dapat dilihat dari kinerja pegawai kecamatan yaitu sejauh mana kecamatan dapat melaksanakan tugas, dalam arti kata pelaksanaan tugas tersebut sesuai dengan apa yang telah direncanakan, sehingga diperoleh hasil yang memuaskan. Maka setiap unsur yang terdapat dalam organisasi kecamatan dituntut untuk memiliki kualitas dan mampu melaksanakan tugas-tugas yang dibebankan, serta mengetahui pekerjaannya dengan mengarah ke tujuan organisasi. Untuk melihat apakah suatu organisasi itu mencapai tujuan, maka diperlukan penilaian terhadap profesionalisme organisasi kecamatan itu sendiri dan kemudian melibatkan evaluasi kinerja sebagai panduan untuk memilih dan merancang bagaimana organisasi kecamatan kedepannya.

Di tengah banyaknya fenomena negatif tentang organisasi pemerintahan daerah terutama daerah kecamatan, baik itu tentang pelayanan yang diberikan kurang baik dan berbelit-belit, ASN kecamatan yang tidak tepat waktu dalam bekerja, ditambah lagi dengan praktek nepotisme. Namun, ada pemberitaan yang cukup asing terdengar dimana organisasi pemerintahan daerah kecamatan, yaitu Kecamatan Bukitraya Kota Pekanbaru memperoleh kinerja terbaik di lingkungan kota Pekanbaru tahun 2014.

Akan tetapi di tahun 2015 kecamatan Bukitraya tidak lagi memperoleh peringkat pertama ataupun kedua dalam hal kinerja ASN. Kecamatan Bukitraya mengalami kemunduran dalam mempertahankan prestasinya. Peringkat I Kecamatan terbaik kinejanya di raih oleh Kecamatan Rumbai Kota Pekanbaru dan disusul Kecamatan Tampan sebagai peraih peringkat II dalam hal kecamatan dengan kinerja terbaik tahun 2015.

Menurut Siagian (2014) profesionalisme diukur dari segi kecepatannya dalam menjalankan fungsi dan mengacu kepada prosedur yang telah disederhanakan. Menurut pendapat tersebut, konsep profesionalisme dalam diri ASN dilihat dari segi.

1. Kreatifitas

Kemampuan ASN untuk menghadapi hambatan dalam memberikan pelayanan kepada publik dalam melakukan inovasi. Hal ini perlu diambil untuk mengakhiri penilaian miring masyarakat kepada birokrasi publik yang dianggapa kaku dalam bekerja. terbentuknya ASN yang kreatif hanya dapat terjadi apabila : terdapat iklim yang kondusif yang mampu mendorong ASN pemerintah untuk mencari ide baru dan konsep baru serta menerapkannya secara inovatif. adanya kesediaan pemimpin untuk memberdayakan bawahan antara lain melalui partisipasi dalam pengambilan keputusan yang menyangkut pekerjaan, mutu hasil pekerjaan, karier dan penyelesaian tugas.

2. Inovasi (Innovasi)

Perwujudannya berupa hasrat dan tekad untuk mencari, menemukan dan menggunakan cara baru, metode kerja baru, dalam pelaksanaan tugasnya. Hambatan yang paling mendasar dari perilaku inovatif adalah rasa cepat puas terhadap hasil pekerjaan yang telah dicapai.

3. Responsifitas (Responsivity)

Kemampuan ASN dalam mengantisipasi dan menghadapi aspirasi baru, perkembangan baru, tuntutan baru, dan pengetahuan baru, birokrasi harus merespon secara cepat agar tidak tertinggal dalam menjalankan tugas dan fungsinya. 


\section{METODE}

Penelitian ini dilaksanakan Kecamatan Bukit Raya Kota Pekanbaru. Populasi dalam penelitian ini adalah ASN Kantor Camat Bukitraya Kota Pekanbaru serta masyarakat yang sedang menggunakan jasa pelayanan di Kantor Camat Bukitraya. Sumber dan jenis data dalam penelitian ini adalah primer dan skunder. Untuk memperoleh data yang diperlukan maka dilakukan dengan teknik wawancara, obeservasi serta kaji dokumen, kemudian dianalisa secara deskriptif kualitatif.

\section{HASIL DAN PEMBAHASAN}

Dari kegiatan penelitian yang dilakukan di peroleh hasil bahwa Profesionalisme ASN di Kantor Camat Bukitraya Kota Pekanbaru belum optimal. Sebagaimana pengukuran tingkat profesionalisme ASN menurut Siagian (2014) profesionalisme diukur dari segi kecepatannya dalam menjalankan fungsi dan mengacu kepada prosedur yang telah disederhanakan. Menurut pendapat tersebut, konsep profesionalisme dalam diri aparat dilihat dari segi.

1. Kreatifitas

2. Inovasi

3. Responsibilitas

Dalam pelaksanaanya di Kantor Camat Bukitraya Kota Pekanbaru dapat dijabarkan sebagaimana berikut:

1. Profesionalisme dari aspek Kreatifitas dan Inovasi

Pada tahun 2016 Kecamatan Bukitraya mulai melakukan pembenahan untuk meningkatkan pelayanan publik dengan adanya launching website Kecamatan Bukitraya yang dilengkapi dengan Forum Diskusi Online sebagai wadah untuk menyampaikan aspirasi masyarakat. Hal ini menunjukkan bahwa Kecamatan Bukitraya mulai mengacu kepada Visi dan Misi Kecamatan yaitu untuk mewujudkan ASN yang prosfesional, dan langkah awalnya dilakukan dengan inovasi untuk meningkatkan pelayanan public.

2. Profesionalisme dari aspek Responsifitas

Profesionalisme ASN di Kantor Camat Bukitraya khususnya aspek responsifitas masih terbentur oleh keberadaan aturan formal yang secara tegas mengatur apa yang menjadi tugas dan fungsi Kecamatan Bukitraya,artinya aparat Kecamatan Bukitraya lebih mengacu kepada petunjuk atasan daripada mengacu kepada masyarakat dengan berinisiatif untuk melakukan perubahan-perubahan yang dapat mempermudah masyarakat untuk mendapatkan pelayanan yang prima. Fenomena tersebut melahirkan patologi birokrasi juklak-juknis dan berorientasi kepada aturan formal (rule-driven professionalism) daripada berorientasi kepada pelayanan.

\section{Faktor yang Mempengaruhi Profesionalisme ASN}

Setelah mencermati dan menganalisa tentang profesionalisme birokrasi Kecamatan Bukitraya yang ditinjau dari aspek responsifitas terhadap tuntutan masyarakat dan perubahan lingkungan serta juga melihat profesionalisme birokrasi khususnya dari aspek inovasi sebagai wujud dari birokrasi profesional yang selalu menciptakan model kerja baru demi peningkatan produktifitas organisasi dan meningkatkan kualitas pelayanan terhadap publik. Dan juga mencermati faktor-faktor apa saja yang menjadi hambatan bagi Kecamatan Bukitraya dalam mengembangkan birokrasi profesional, maka berikut ini akan ditampilkan keterkaitan antara profesionalisme birokrasi dilihat dari aspek responsifitas dan inovasi dengan faktor visi- misi organisasi, struktur organisasi, faktor kepemimpinan, serta faktor penghargaan :

1. Keterkaitan antara profesionalisme dengan visi-misi organisasi. 
Visi-misi bagi sebuah organisasi merupakan cita cita yang ingin dicapai dan diwujudkan dalam langkah langkah strategis oleh individu di dalam organisasi tersebut. Dalam hal ini organisasi Kecamatan Bukitraya sudah memiliki visi-misi yang baik dan berpihak kepada masyarakat namun dalam praktek, misi sebagai cara untuk mewujudkan visi hanya merupakan hiasan dinding yang selalu dilihat saja. Organisasi Kecamatan Bukitraya lebih digerakkan oleh aturan aturan formal yang menjelaskan secara tegas apa yang harus dilakukan oleh masing masing elemen dalam Kecamatan Bukitraya. Konsekuensi dari cara kerja yang berorientasi pada peraturan membuat birokrasi Kecamatan Bukitraya menjadi tidak responsif dan inovatif hanya merupakan sebuah angan-angan indah yang sulit untuk diwujudkan karena keberadaan aturan yang membuat mereka menjadi robot daripada manusia yang memiliki jiwa "entrepreneur" dalam mensikapi perubahan lingkungan.

2. Keterkaitan antara profesionalisme dengan Struktur Organisasi.

Struktur organisasi Kecamatan Bukitraya dengan model "lini dan staff" dimana peran pemimpin dalam struktur tersebut sangat dominan baik dalam proses pengambilan keputusan maupun peran pengawasan terhadap setiap aktifitas yang dilakukan. Namun wewenang yang bersifat strategis tidak berada pada pundak pimpinan puncak, karena wewenang strategis seperti rekruitmen tenaga baru, perubahan dalam persyaratan pelayanan harus melalui eksekutif puncak (Walikota). Sentralisasi kewenangan pada Pemerintah kota jika tetap dipertahankan hanya akan mematikan partisipasi bawahan dalam mensikapi setiap perubahan yang terjadi. Struktur organisasi Kecamatan Bukitraya juga perlu mendapat perhatian dalam pembagian tugas. Pembagian tugas dalam organisasi lebih mengacu kepada peraturan formal daripada mengacu kepada misi yang hendak dicapai. Dengan tidak adanya wewenang yang sifatnya strategis pada pimpinan puncak dan pembagian tugas yang didasarkan kepada aturan formal hanya akan membuat aparat menjadi boneka atau robot dari eksekutif puncak dan membuat aparat menjadi tidak peka dan kurang merespon aspirasi masyarakat.

3. Keterkaitan antara profesionalisme dengan faktor Kepemimpinan.

Kepemimpinan sangat diperlukan dalam setiap organisasi. Peran pemimpin sebagai pengarah dan memiliki jiwa dan pandangan visioner sangat diperlukan amun dalam lingkungan Kecamatan Bukitraya, peran pemimpin belum mampu memainkan peran ideal tersebut. Langkah-langkah konkrit pemimpin dalam menciptakan iklim demokrasi dimana bawahan disertakan dalam setiap pengambilan kebijakan yang berkaitan dengan peningkatan kinerja organisasi serta membangun komunikasi dua arah dalam setiap kegiatan akan membuat bawahan merasakan diri mereka adalah bagian dari organisasi. Tampaknya hal tersebut masih jauh dari kenyataan khususnya dalam lingkungan Kecamatan Bukitraya. Bawahan cenderung menjadi pelaksana saja dalam setiap kegiatan yang dinstruksikan oleh atasan dan bekerja berdasarkan apa yang telah ditetapkan dalam peraturan. Sikap pemimpin untuk menumbuhkan jiwa responsif dan inovatif belum terwujud akibatnya bawahan enggan dan tidak berani bertindak diluar ketentuan dan perintah atasan.

4. Keterkaitan antara profesionalisme dengan faktor penghargaan

Hal yang dapat menjadi motivasi seseorang untuk bekerja keras dan berprestasi adalah mendapatkan penghargaan yang layak bagi dirinya dan keluarga serta kepuasan kerja, namun rendahnya responsifitas dan inovasi yang dilakukan oleh jajaran birokrasi Kecamatan Bukitraya juga disebabkan oleh model penghargaan yang diberikan dimana penghargaan tersebut belum mencerminkan keadilan berdasarkan tingkat kesulitan pekerjaan dan juga tidak menghargai prestasi seorang ASN.

Prestasi seorang ASN, rajinnya seorang ASN belum menjamin untuk mendapatkan penghargaan yang layak dan mendapatkan jabatan yang dinginkan. Sistem penghargaan yang ada selama ini telah mematikan motivasi ASN untuk bersikap responsif dan berinovasi, dimana ASN yang bermotivasi tinggi hanya akan mengalami kekecewaan dalam dirinya dan dapat mempengaruhi motivasinya karena dalam dunia birokrasi, senioritas menjadikan segala bentuk kualitas dalam diri ASN baru yang berprestasi dan bermotivasi untuk mengubur impinannya dalam-dalam. 


\section{KESIMPULAN}

Responsifitas dan inovasi aparatur Kecamatan Bukitraya baik dalam rangka pelayanan kepada masyarakat maupun dalam pelaksanaan tugas-tugas yang lain sudah mulai mengarah kepada visi dari kecamatan Bukitraya yaitu Terwujudnya Kecamatan Bukitraya Yang Profesional Dalam Penyelenggaraan Pemerintahan Dan Pelayanan Kepada Masyarakat, hanya saja belum terlaksana secara optimal. Memberikan motivasi dan kesempatan seluas-luasnya kepada para pegawai untuk menambah pengetahuan dan peningkatan ketrampilan.

\section{DAFTAR PUSTAKA}

[1]. Agung, Kurniawan 2005. Transformasi Pelayanan Publik. Yogyakarta: Pembaharuan

[2]. Creswell, John. W. Research Design, Qualitative and Quantitative Aproaches, Jakarta : KIK Press.

[3]. J. Moleong, Lexi. 2005. Metode Penelitian Kualitatif. Bandung : PT. Remaja Rosdakarya.

[4]. K. Yin, Robert. 2003. Studi Kasus (Desain dan Metode), Jakarta : PT. Raja Grafindo Persada.

[5]. Sedarmayanti,2011. Manajemen Sumber Daya Manusia, Reformasi Birokrasi dan Manajemen Pegawai Negeri Sipil. Bandung: PT Refika Aditama.

[6]. Saputra, T. (2016). Pengaruh Motivasi Kerja Terhadap Disiplin Kerja Pegawai Pada Dinas Pemuda Dan Olahraga Provinsi Riau. Jurnal Niara, 8(2), 50-60.

[7]. Siagian P. Sondang, 2014. Administrasi Pembangunan. Jakarta: Bumi Akarsa.

[8]. Siagian, Sondang, P. 2004. Patologi Birokrasi, Galia Indonesia, Jakarta.

[9]. Sugiyono. 2005. Memahami Penelitian Kualitatif. Bandung: CV. Alfabeta.

[10]. Simamora, Henry, 2007. Manajemen Sumber Daya Manusia, STIE TKPN, Yogyakarta.

[11]. Tjokrowinoto, Muljarto. 2006. Pembangunan, Dilema dan Tantangan, Pustaka Pelajar, Yogyakarta.

[12]. Widodo, Joko. 2005. Membangun Birokrasi: Berbasis Kinerja. Malang: Bayu Media Publishing. 